\title{
Modelling and Simulation of Natural Gas Liquefaction Process
}

\author{
Alessandro Trigilio, Alexis Bouza and Sabrina Di Scipio \\ Thermodynamics and Transport Phenomena Department, Simón Bolívar University \\ Venezuela
}

\section{Introduction}

The global energy demand is increasing and the natural gas (NG) has obtained relevance as a clean fuel. At distances greater than $4000 \mathrm{~km}$ from the source of production, the most profitable way of transportation for the NG is as liquefied natural gas (LNG). Between years 2000-2010 the natural gas consumption increased 31.4\% and LNG represents $30.5 \%$ of the global NG trade in 2010 (British Petroleum, 2011). With a world market in full development and a global perspective with a strong trend towards globalization and free trade, it is evident the importance of gas liquefaction processes.

LNG is obtained when the NG is cooled until its bubble point (or even below) at atmospheric pressure, which corresponds to $-161^{\circ} \mathrm{C}$. At this point, its density is $55 \%$ lower than the water and its volume is reduced 600 times. The volume reduction favours not only the transport (using LNG carriers) but also the storage in tanks (Institute for Energy, Law \& Enterprise - University of Houston, 2003).

The number of installed plants for the NG liquefaction had a significant increase since 1960 (Haselden, 1977), as well as the operational improvements. The current installed plants are capable of processing more than 4 MTPA of NG.

In general, refrigeration cycles used to liquefy natural gas can be split into two main processes: 1) those that use pure refrigerants and 2) those that use mixtures of them. Each technology has its own properties and they have been consolidated as international patents, which seek to optimize energy consumption, capital investment and the physical space occupied by the required equipment.

Previous studies related with LNG processes using mixed refrigerant (MR) have been published. Del Nogal et al. (2005) optimized the mixed refrigerant composition focused on minimizing the power in the compression stages, but the complete model was not shown. Jensen \& Skogestad (2006) proposed a control strategy for the process, based on a certain control and instrumentation philosophy, without reporting the process model. Jensen and Skogestad as well as Lee et al. (2002) optimized the refrigerant composition with the aim of minimizing the temperature gap between the natural gas and the mixed refrigerant in the cycle evaporator. Aspelund et al. (2010) optimized the refrigerant composition in three different ways: 1) using a fixed minimum internal temperature approach, 2) using a fixed exchanger area and 3) minimizing the cost for exchanger area, but again not model details were shown. 
On the other hand, Haselden (1977) shown optimum operating conditions for cycles in cascade with three pure refrigerants, based on the operational experience of installed LNG plants. It is evident that there are very few attempts to model the processes for liquefying natural gas. Moreover, none of the above works show in detail a complete set of operating conditions for these systems.

Consequently, the purpose of this work is to model and simulate the natural gas liquefaction process in stationary state, using cycles with MR and cascade cycles with pure refrigerants. The specific objectives are:

- Calculate energetic properties and phase equilibria using the Peng-Robinson equation of state.

- Simulate the NG liquefaction process using mixed or pure refrigerants (considering traditional and optimized cascades), by developing Matlab® routines. The technical feasibility of operating conditions will be evaluated

- $\quad$ Based on the developed models, a sensitivity analysis of the variables involved will be made in order to determine its impact on operating conditions.

\section{Refrigeration cycles}

A refrigeration cycle uses changes in pressure and temperature on a mixed or pure compound (named refrigerant) in order to transfer heat from a cold zone (or fluid) to a hot zone (or fluid). In Fig. 1 is shown a simple throttle valve cycle, consisting in two heat exchangers, a throttle valve and a compressor.

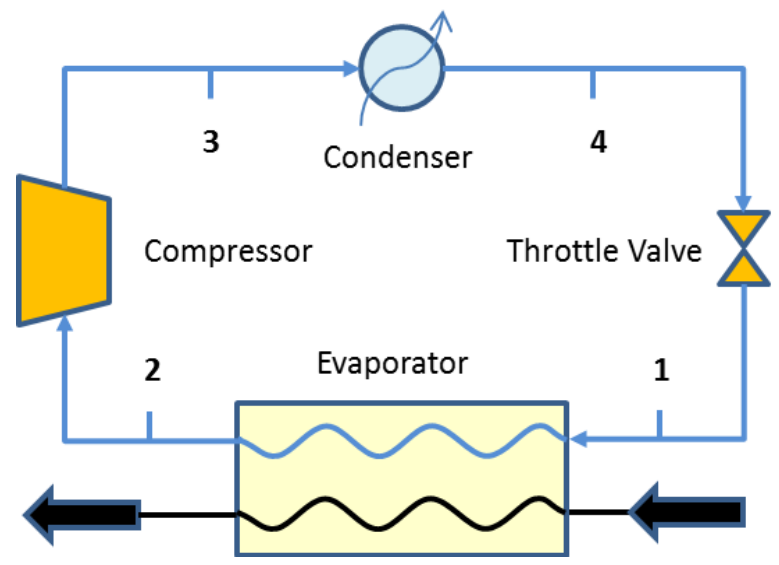

Fig. 1. Simple refrigeration cycle using a throttle valve.

The refrigerant is in a vapour-liquid equilibrium (stream 1) when enters the evaporator and exchanges heat with the hot source, until reaching saturation or even becoming overheated vapour (stream 2 ). Then, enters the compressor and suffers a pressure and temperature rise. The refrigerant in stream 3 exchanges heat with a cold source in the condenser, becoming liquid and entering to the throttle valve (stream 4), where it expands and its temperature falls to a minimum, starting the cycle again. 
If the throttle valve is considered adiabatic, the First Law of Thermodynamics reveals that the expansion is isenthalpic. Moreover, if the compressor is adiabatic and the compression is reversible, then it is isentropic (Çengel \& Boles, 2006). The existence of internal friction and the heat leaks to the surroundings result in a deviation from the isentropic behaviour, therefore is required the use of a polytropic efficiency $\left(N_{p}\right)$.

\subsection{Polytropic work in the compressor}

The polytropic work $\left(W_{\text {poli }}\right)$ in the compressor is used in order to determine the polytropic efficiency ( $N p)$ of the gas compression process, as shown in Eqs. (1) - (4) (Walas, 1990).

$$
\begin{gathered}
W_{\text {poly }}=\frac{k}{k-1} \cdot z \cdot R \cdot T \cdot\left[\left(\frac{P_{2}}{P_{1}}\right)^{\frac{n-1}{n}}-1\right] \\
n=\frac{k \cdot N_{p}}{1-k \cdot\left(1-N_{p}\right)} \\
k=\frac{C_{p}}{C_{v}} \\
C_{v}=C_{p}+R
\end{gathered}
$$

where $C p$ is the heat capacity at constant pressure, $R$ is the universal gas constant, $z$ is the gas compressibility factor, $P_{1} / P_{2}$ is the pressure ratio and $T$ is the inlet temperature.

\subsection{Coefficient of performance}

The Coefficient of Performance (COP) for a refrigeration cycle relates the amount of heat taken from the hot source $\left(Q_{\text {evap }}\right)$ and the total work used $\left(W_{\text {comp }}\right)$, as shown in Eq. (5) (Çengel \& Boles, 2006).

$$
\mathrm{COP}=\frac{Q_{\text {evap }}}{W_{\text {comp }}}
$$

A First Thermodynamic Law balance in the refrigerant relates the heats (including the condenser heat, $\mathrm{Q}_{\text {cond }}$ ) and work in any refrigeration cycle, as seen in Eq. (6).

$$
Q_{\text {evap }}=Q_{\text {cond }}-W_{\text {comp }}
$$

Substitution of Eq. (6) in Eq. (5) gives Eq. (7), which is an alternative form for the COP.

$$
\mathrm{COP}=\frac{Q_{\text {cond }}}{W_{\text {comp }}}-1
$$


In order to improve the performance of the cycle, it's important to maximize the COP. In that way it is removed as much heat as possible from the hot source, using the minimum work. It is important to note that, according to Eq. (7), the greater the COP greater the heat retired in the condenser for cooling the refrigerant, then more amount of utility stream is needed.

\subsection{Refrigeration cycles in cascade}

When there is a great gap between the temperature of the hot and cold zones (or fluids) and it is not possible to use only one refrigerant, the cascade cycles are used (Smith, 2005). This configuration uses more than one individual cycles with a common heat exchanger between cycles. The condenser of a cold cycle is the evaporator of the following hotter cycle, as shown in Fig. 2.

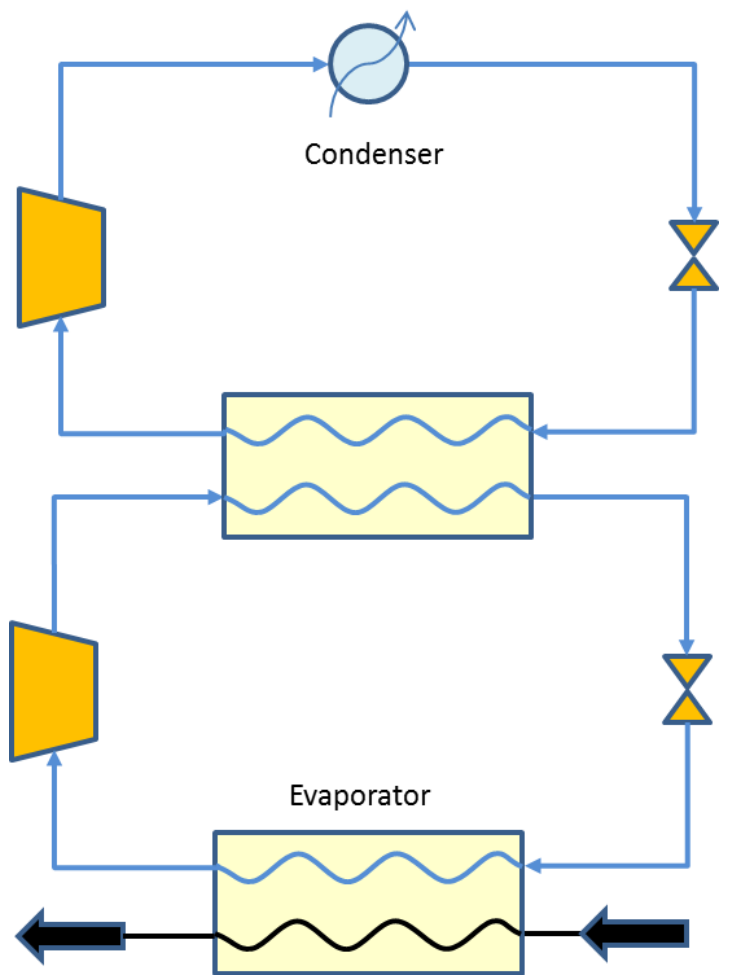

Fig. 2. Refrigeration cycle using a double cascade.

The advantages of using cascade cycles are: better distribution on the refrigerant load, decrease of the required work, and increase of the heat transferred in the non-common evaporator. Hence, the COP increases when this configuration is used.

These cycles are particularly useful in the liquefaction of natural gas because it is possible to cool it and achieve the desired temperatures using water as the external fluid (utility stream) in the condenser. Therefore, it is important to choose the right refrigerant for each cascade. 


\subsection{Refrigerant selection}

In order to guarantee a minimum area in the heat exchangers, the refrigerant used usually is a pure compound, so the phase changes described previously occurs at a constant temperature and the drive force is maintained constant. In Fig. 3 is plotted the saturation curve for the liquid-vapor equilibria for some refrigerant commonly used in the liquefaction of natural gas (obtained from Lemon et al., 2005).

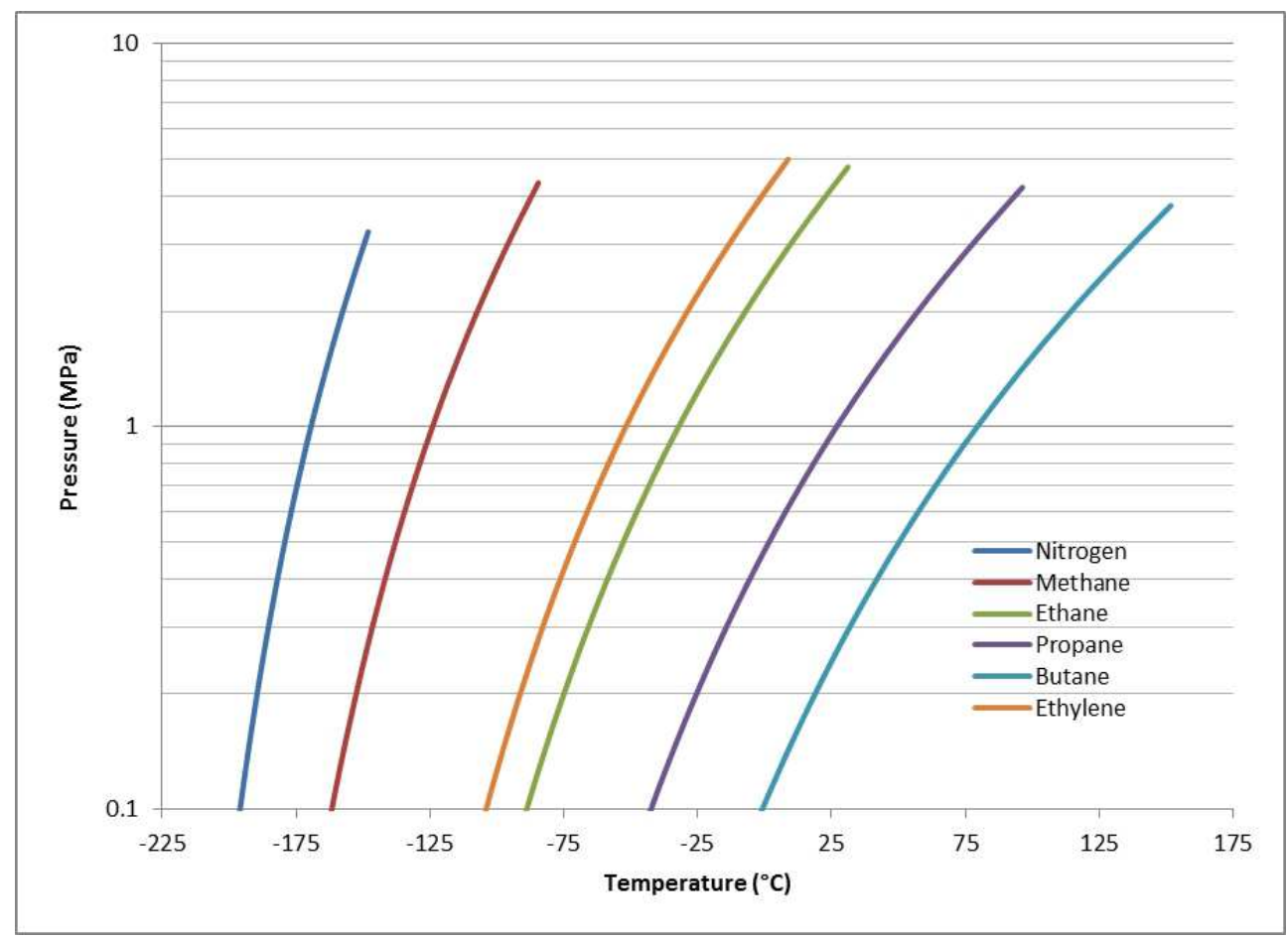

Fig. 3. Vapor pressure curves for refrigerants commonly used to produce LNG.

It should be noted that if the natural gas is between $50^{\circ} \mathrm{C}$ and $-160{ }^{\circ} \mathrm{C}$, these refrigerants can be used depending on the specifications of the process. For example, below $1 \mathrm{MPa}$ and in the range of $-125^{\circ} \mathrm{C}$ to $-160^{\circ} \mathrm{C}$, only methane can be used.

The natural gas is a mixture, mainly composed of methane and small quantities of ethane, propane and others, so the NG phase change occurs at non constant temperature. Despite the driving force, in the liquefaction cycles it is preferred to have a refrigerant cooling curve similar to the NG cooling curve (Smith, 2005). This reduces the energy consumption due to exergy considerations (Haselden, 1977). This can be achieved in two ways. The first is using more than one consecutive refrigeration cycle operating at different pressure levels, obtaining a discrete refrigerant temperature profile (as illustrated in Fig. 4). If more cycles 
are used, the whole process is more efficient, but implies larger amount of equipment required, and therefore a more complex system. The alternative way is to use a mixed refrigerant with a cooling curve as near as possible to the natural gas cooling curve, avoiding temperature cross between the two fluids.

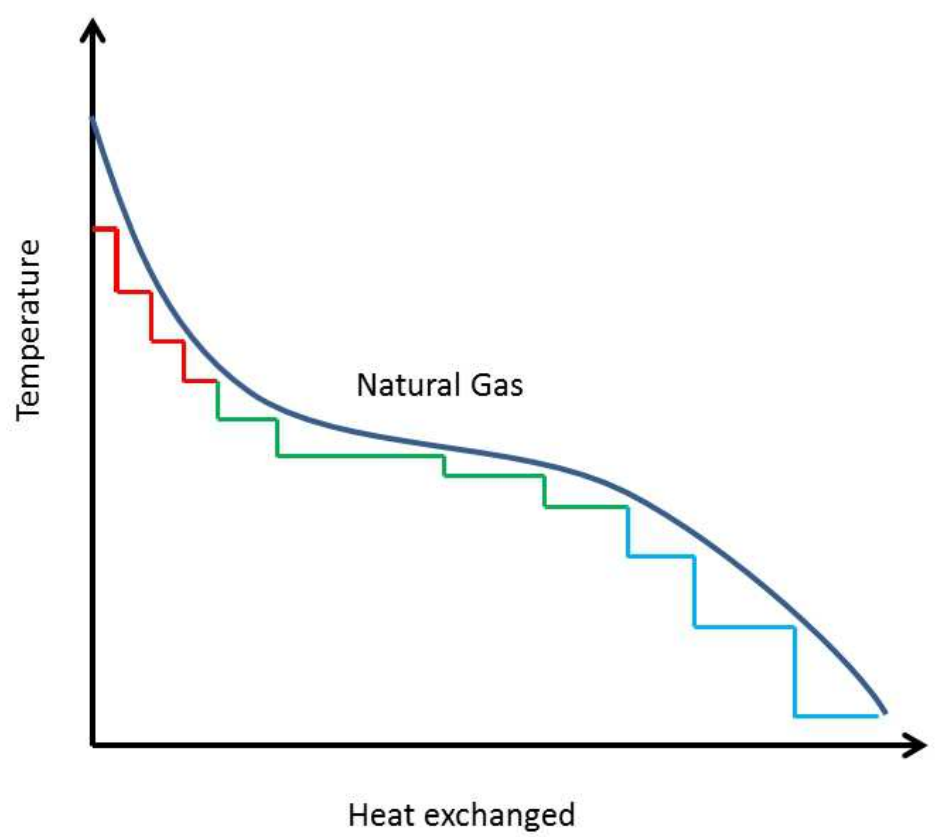

Fig. 4. Discrete refrigerant temperature profile using more than one cycle.

\subsection{Natural gas liquefaction technologies}

The most common technologies used for the natural gas liquefaction can be divided in two main groups according to the refrigerant used: those with pure refrigerant and those with mixed refrigerant. In this work two of the most used configurations have been selected (one of each group) for the modelling and simulation task.

\subsubsection{Pure refrigerant cascade}

Unlike the cycles explained in section 2.2, the cascade cycles used for the natural gas liquefaction usually have more than two cascade, and more than one common heat exchanger between them (as illustrated in Fig. 5). The main idea is to use the internal cycles to cool not only the natural gas, but also the refrigerants in the external cascade. Using cascades makes possible to work in a wide temperature range, so it can be employed cooling water as an external fluid in the evaporator. Also, the cascades improve the COP because of the temperature profile approach between the different refrigerants used and the natural gas, as seen in Fig. 4 . 


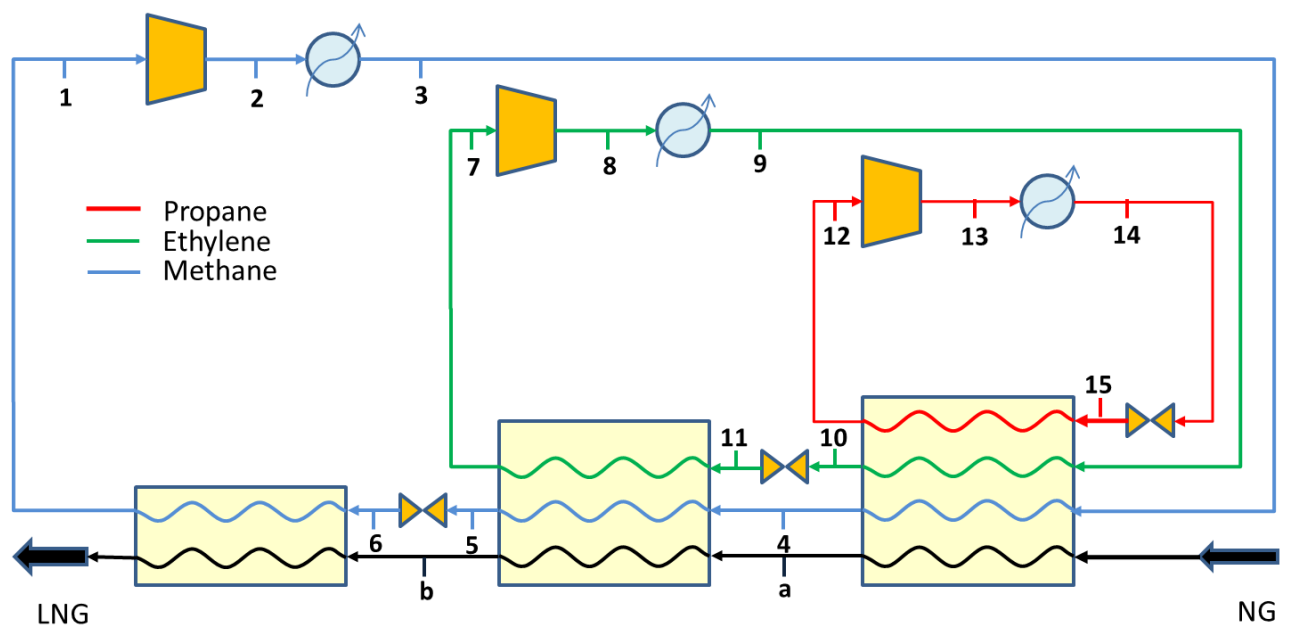

Fig. 5. Triple cascade liquefaction cycle with pure refrigerant.

\subsubsection{Simple cycle with mixed refrigerant}

As explained in section 2.4, the aim of using mixed refrigerants (MR) is for minimizing the approach between the cooling curves in the evaporator. One of the advantages of this cycles is the less amount of equipment required and, depending on the plant load, it is possible to use a single compressor if the power required is no more than 70 MW (Price \& Mortko, 1996).

The cycle configuration is shown in Fig. 6. It is important to note the use of a double pass on the evaporator. According to Price \& Mortko (1996), its purpose is to have best control over the

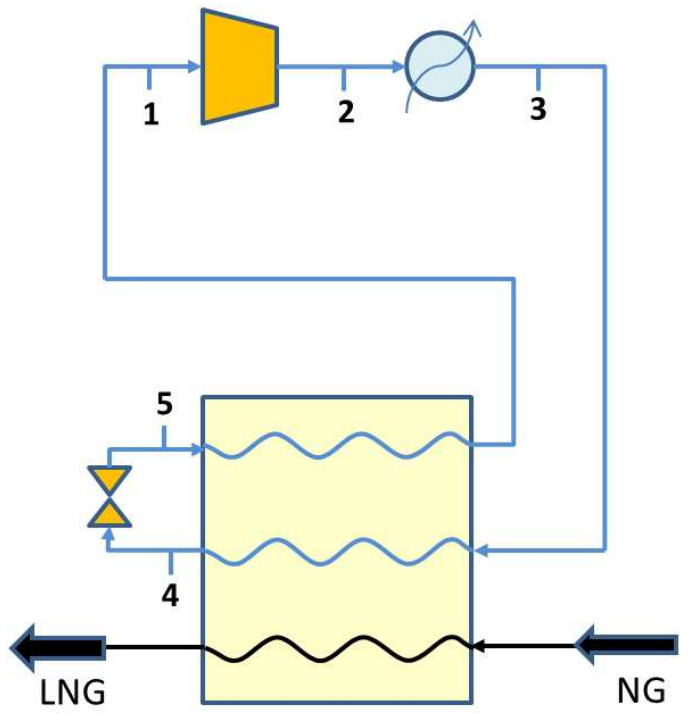

Fig. 6. Simple liquefaction cycle with mixed refrigerant. 
temperature profile due to the possibility of using intermediate separators for the formed vapor, so the mixture composition can be regulated without interrupting the plant operation.

\section{Modelling the liquefaction cycles}

In order to model the stages described in Section 2, is necessary to use a thermodynamic model for the liquid-vapour equilibria and the energy properties, required for the work and heat calculations.

The Peng \& Robinson (1976) equation of state was used. The vapour $\left(y_{i}\right)$ and liquid $\left(x_{i}\right)$ composition of each component (i) in phase equilibria can be related by Eq. (8). The thermodynamic model is used for the fugacity calculation in each phase $\left(\hat{\phi}_{i}^{l}, \hat{\phi}_{i}^{v}\right)$, expressed in Eqs. (9) - (19). When performing iterative calculations, each side of the Eq. (8) should be satisfied.

$$
\begin{aligned}
& k_{i}=\frac{y_{i}}{x_{i}}=\frac{\hat{\phi}_{i}^{v}}{\hat{\phi}_{i}^{l}} \\
& \ln \hat{\phi}_{i}=\frac{b}{b_{i}} \cdot(Z-1)-\ln (Z-B)-\frac{A}{2 \cdot \sqrt{2}} \cdot\left(\frac{2 \cdot \sum_{j} x_{j} \cdot a_{i j}}{a}-\frac{b_{i}}{b}\right) \cdot \ln \left[\frac{Z+(1+\sqrt{2}) \cdot B}{Z-(1-\sqrt{2}) \cdot B}\right] \\
& Z^{3}-(1-B) \cdot Z^{2}+\left(A-3 \cdot B^{2}-2 \cdot B\right) \cdot Z-\left(A \cdot B-B^{2}-B^{3}\right)=0 \\
& A=\frac{a \cdot P}{R^{2} \cdot T^{2}} \\
& B=\frac{b \cdot P}{R \cdot T} \\
& a=\sum_{i} \sum_{j} x_{i} \cdot x_{j} \cdot a_{i j} \\
& a_{i j}=\left(1-\delta_{i j}\right) \cdot a_{i}{ }^{1 / 2} \cdot a_{j}^{1 / 2} \\
& a_{i}=0.45724 \cdot \alpha_{i} \cdot \frac{R^{2} \cdot T c_{i}^{2}}{P c_{i}} \\
& \alpha_{i}{ }^{1 / 2}=1+m_{i} \cdot\left[1-\left(\frac{T}{T c_{i}}\right)^{1 / 2}\right] \\
& m_{i}=0.37464+1.54226 \cdot \omega_{i}-0.26992 \cdot \omega_{i}^{2}
\end{aligned}
$$




$$
\begin{gathered}
b=\sum_{i} x_{i} \cdot b_{i} \\
b_{i}=0.07780 \cdot \frac{R \cdot T c_{i}}{P c_{i}}
\end{gathered}
$$

where $T c_{i}$ and $P c_{i}$ are the critical temperature and pressure of the component $i$, and $\omega_{i}$ is its accentric factor (Green \& Perry, 2008).

If there are only hydrocarbons in the mixture, the binary interaction parameter $\left(\delta_{\mathrm{ij}}\right)$ is zero. On the other hand, if nitrogen is present Nikos (1986) deduced temperature and pressure dependent correlations for this parameter (Eqs. (20) - (24)).

$$
\begin{gathered}
\delta_{i j}{ }^{\prime}=\eta_{2} \cdot\left(\frac{T}{T c_{j}}\right)^{2}+\eta_{1} \cdot \frac{T}{T c_{j}}+\eta_{0} \\
\eta_{0}=0.1751787-0.7043 \cdot \log \omega_{j}-0.862066 \cdot\left(\log \omega_{j}\right)^{2} \\
\eta_{1}=-0.54474+1.328 \cdot \log \omega_{j}+2.035767 \cdot\left(\log \omega_{j}\right)^{2} \\
\eta_{2}=2.257079+7.869765 \cdot \log \omega_{j}+13.50466 \cdot\left(\log \omega_{j}\right)^{2}+8.3864 \cdot\left(\log \omega_{j}\right)^{3} \\
\delta_{i j}=\delta_{i j} \cdot\left(1.04-4.2 \cdot 10^{-5} \cdot P\right)
\end{gathered}
$$

In order to determine the heats and works is necessary to calculate the enthalpy for each stream of the cycle. This can be done using Eq (25) taking as a reference state $0 \mathrm{~J} / \mathrm{mol}$ when the temperature is $0{ }^{\circ} \mathrm{C}$ as an ideal gas. The residual enthalpy $\left(h^{r e s}\right)$ for the Peng-Robinson equation of state is calculated using Eqs. (26) and (27).

$$
\begin{gathered}
h=h^{r e f}+\sum_{i} x_{i} \cdot \int_{273.15 K}^{T} C_{p}^{i g} \cdot d T-h^{r e s} \\
\frac{h^{r e s}}{R \cdot T}=(1-Z)+\frac{a+D}{2 \cdot \sqrt{2} \cdot R \cdot T \cdot b} \cdot \ln \left[\frac{Z+(1+\sqrt{2}) \cdot B}{Z+(1-\sqrt{2}) \cdot B}\right] \\
D=\sum_{i} \sum_{j} y_{i} \cdot y_{j} \cdot \kappa_{j} \cdot\left(1-\delta_{i j}\right) \cdot \sqrt{a_{i}} \cdot \sqrt{\frac{a_{j}}{\alpha_{j}} \cdot \frac{T}{T c_{j}}}
\end{gathered}
$$

The heat capacity at constant pressure (Cpig) is calculated using Eq. (28), and the coefficients where taken from Green \& Perry (2008).

$$
C_{p}^{i g}=C_{1}+C_{2} \cdot\left[\frac{C_{3} / T}{\sinh \left(C_{3} / T\right)}\right]^{2}+C_{4} \cdot\left[\frac{C_{5} / T}{\cosh \left(C_{5} / T\right)}\right]^{2}
$$


The liquefaction cycles where simulated using Matlab®. The conditions used for all the cycles were:

- The amount natural gas processed was 4 MTPA, equivalent to $26220 \mathrm{kmol} / \mathrm{h}$.

- The throttle valve and the compressors were considered adiabatic.

- The pressure drops in the heat exchanger was set to $20 \mathrm{kPa}$ on the cold side and $50 \mathrm{kPa}$ on the hot side.

- The utility stream in the condensers was cooling water, so its temperature is $12^{\circ} \mathrm{C}$.

- The outlet temperature for the LNG from the evaporators is set to $-153^{\circ} \mathrm{C}$ (below its bubble point).

- It should be verified that the temperature at the compressor entrance is above the dew point.

- At the exit of common evaporators, all the streams have the same temperature (valid for streams a and b in Fig. 5 to 8).

- The LNG goes through a throttle valve after the evaporators, and its final outlet pressure is $180 \mathrm{kPa}$, as a liquid-vapor mixture with a vaporized fraction less than $1 \%$.

- The initial conditions for the natural gas and its composition are shown in Table 1.

\begin{tabular}{|l|l|}
\hline Methane $(\% \mathrm{~mol})$ & 0.924 \\
\hline Ethane $(\% \mathrm{~mol})$ & 0.056 \\
\hline Propane $(\% \mathrm{~mol})$ & 0.019 \\
\hline n-Butane $(\% \mathrm{~mol})$ & 0.001 \\
\hline GN Inlet Temperature $\left({ }^{\circ} \mathrm{C}\right)$ & 15 \\
\hline GN Inlet Pressure $(\mathrm{kPa})$ & 6000 \\
\hline
\end{tabular}

Table 1. NG composition and inlet conditions.

\subsection{Modelling of the cascade cycles}

In order to verify the advantages of using cascade cycles, three cases were simulated. In general, the refrigerant must be selected to satisfy that the enthalpy at the condenser outlet (at the highest pressure and with the chosen utility) is such that the valve outlet temperature is cooler than the temperature desired for the natural gas.

In Fig. 7 is illustrated a simple cycle using methane in traditional cascade. According to the Figure 3 , the methane cannot be used with an utility stream at $12{ }^{\circ} \mathrm{C}$. In order to use this refrigerant two traditional cascades were added.

The second configuration is illustrated in Fig. 8. It is an intermediate between the one shown in Fig. 5 and Fig. 7. The principle is the same explained in Section 2.5.1, the internal refrigerants has to cool the natural gas and also the refrigerants in the external cycle. The third case is the complete cascade as in the Fig. 5.

In Table 2 initial operating conditions for the cascade cycles are shown. The number of variables specified where obtained after a degree of freedom analysis. The temperatures were set to guarantee the cooling of the NG according to the pressure levels. 


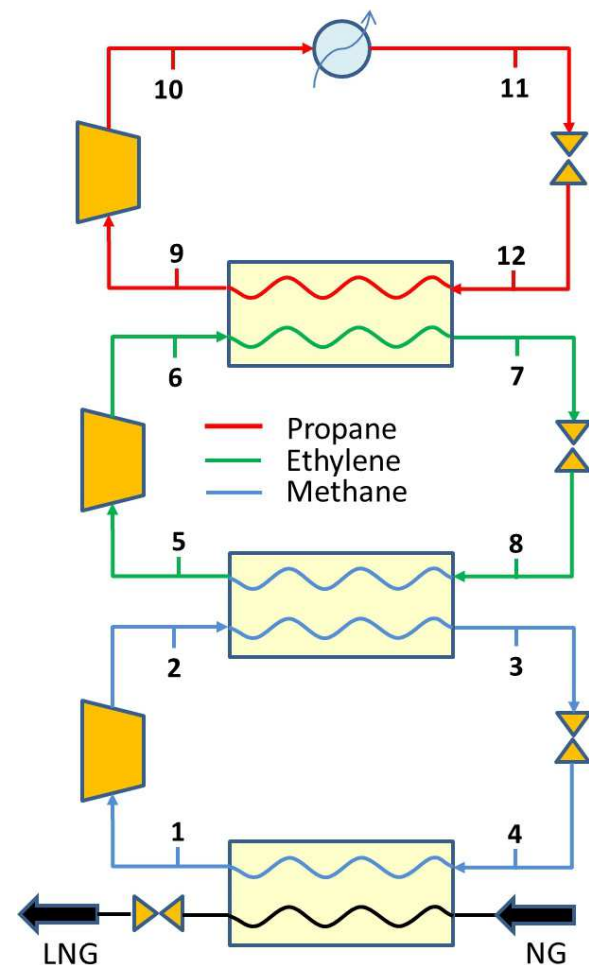

Fig. 7. Triple cascade in traditional configuration.

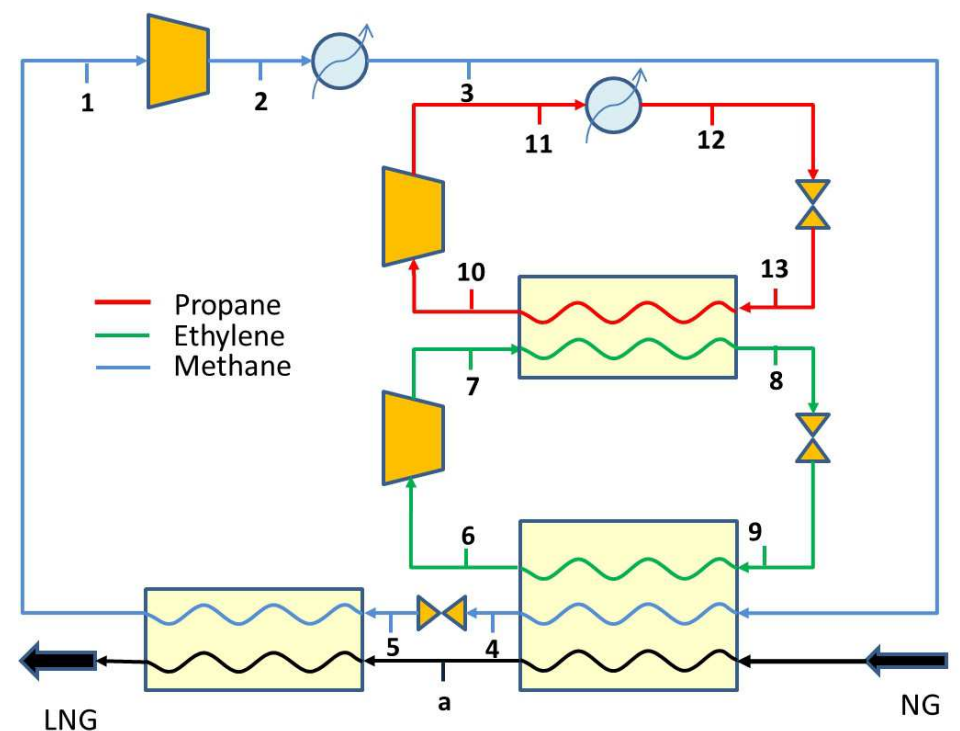

Fig. 8. Triple cascade in hybrid configuration. 


\begin{tabular}{|c|c|c|c|}
\hline Stream & Traditional Cascade & Hybrid Cascade & Triple Cascade \\
\hline 1 & $\mathrm{~T}=-155^{\circ} \mathrm{C}$ & $\mathrm{T}=-155^{\circ} \mathrm{C}$ & $\mathrm{T}=-155^{\circ} \mathrm{C}$ \\
\hline 2 & $\mathrm{~T}=61^{\circ} \mathrm{C} ; \mathrm{P}=4000 \mathrm{kPa}$ & $\mathrm{T}=61{ }^{\circ} \mathrm{C} ; \mathrm{P}=4000 \mathrm{kPa}$ & $\mathrm{T}=61^{\circ} \mathrm{C} ; \mathrm{P}=4000 \mathrm{kPa}$ \\
\hline 3 & $\mathrm{~T}=-94^{\circ} \mathrm{C}$ & $\mathrm{T}=12^{\circ} \mathrm{C}$ & $\mathrm{T}=12^{\circ} \mathrm{C}$ \\
\hline 4 & $\mathrm{P}=140 \mathrm{kPa}$ & $\mathrm{T}=-94^{\circ} \mathrm{C}$ & $\mathrm{T}=-30^{\circ} \mathrm{C}$ \\
\hline 5 & $\mathrm{~T}=-96^{\circ} \mathrm{C}$ & $\mathrm{P}=140 \mathrm{kPa}$ & $\mathrm{T}=-94{ }^{\circ} \mathrm{C}$ \\
\hline 6 & $\mathrm{~T}=79^{\circ} \mathrm{C}, \mathrm{P}=1950 \mathrm{kPa}$ & $\mathrm{T}=-96^{\circ} \mathrm{C}$ & $\mathrm{P}=140 \mathrm{kPa}$ \\
\hline 7 & Vaporized fraction$=0.2$ & $\mathrm{~T}=79{ }^{\circ} \mathrm{C}, \mathrm{P}=1950 \mathrm{kPa}$ & $\mathrm{T}=-96{ }^{\circ} \mathrm{C}$ \\
\hline 8 & $\mathrm{P}=140 \mathrm{kPa}$ & Vaporized fraction $=0.2$ & $\mathrm{~T}=79{ }^{\circ} \mathrm{C}, \mathrm{P}=2000 \mathrm{kPa}$ \\
\hline 9 & $\mathrm{~T}=-32{ }^{\circ} \mathrm{C}$ & $\mathrm{P}=140 \mathrm{kPa}$ & $\mathrm{T}=12^{\circ} \mathrm{C}$ \\
\hline 10 & $\mathrm{~T}=38^{\circ} \mathrm{C}, \mathrm{P}=750 \mathrm{kPa}$ & $\mathrm{T}=-32{ }^{\circ} \mathrm{C}$ & Vaporized fraction $=0.2$ \\
\hline 11 & $\mathrm{~T}=12{ }^{\circ} \mathrm{C}$ & $\mathrm{T}=38^{\circ} \mathrm{C}, \mathrm{P}=750 \mathrm{kPa}$ & $\mathrm{P}=140 \mathrm{kPa}$ \\
\hline 12 & $\mathrm{P}=120 \mathrm{kPa}$ & $\mathrm{T}=12{ }^{\circ} \mathrm{C}$ & $\mathrm{T}=-32{ }^{\circ} \mathrm{C}$ \\
\hline 13 & - & Vaporized fraction=0.2 & $\mathrm{T}=38^{\circ} \mathrm{C}, \mathrm{P}=750 \mathrm{kPa}$ \\
\hline 14 & - & - & $\mathrm{T}=12{ }^{\circ} \mathrm{C}$ \\
\hline 15 & - & - & Vaporized fraction $=0.2$ \\
\hline
\end{tabular}

Table 2. Initial operating conditions for the cascade cycles.

The refrigerant load is unknown, and its value is calculated using an energy balance in the evaporators. For example, in the triple cascade (Fig. 5) the three energy balances are presented in Eqs. (29) - (31), as a function of enthalpies and flow rates (F). As can be seen in these equations, the inner cycle energy balance depends on the external cycle flow rate, so the cascades should be solved starting from the external cycle.

$$
\begin{gathered}
F_{\text {methane }}=\frac{F_{N G} \cdot\left(h_{L N G}-h_{b}\right)}{h_{6}-h_{1}} \\
F_{\text {ethylene }}=\frac{F_{\text {methane }}\left(h_{5}-h_{4}\right)+F_{N G}\left(h_{b}-h_{a}\right)}{h_{11}-h_{7}} \\
F_{\text {propane }}=\frac{F_{\text {ethylene }} \cdot\left(h_{10}-h_{9}\right)+F_{\text {methane }} \cdot\left(h_{4}-h_{3}\right)+F_{N G} \cdot\left(h_{a}-h_{N G}\right)}{h_{15}-h_{12}}
\end{gathered}
$$

\subsection{Modelling of simple cycles}

After a freedom degree analysis, the conditions for the simple cycle were set as shown in Table 3. The pressure level is important because the temperature at the valve outlet (Fig. 6) should be less than the temperature at the inlet, and this value should be cooler than the LNG final temperature.

The composition of the mixed refrigerant was also a variable. A base case composition was used as well as others optimized compositions found in the literature, in order to compare the results, even if the optimizations were carried out at different conditions than the used in the present work. These compositions are presented in Table 1Table 4. 


\begin{tabular}{|c|c|}
\hline Stream & Operating Condition \\
\hline 1 & $\mathrm{~T}=-6^{\circ} \mathrm{C}$ \\
\hline 2 & $\mathrm{P}=3000 \mathrm{kPa}, \mathrm{T}=-1^{\circ} \mathrm{C}$ \\
\hline 3 & $\mathrm{~T}=12^{\circ} \mathrm{C}$ \\
\hline 4 & $\mathrm{~T}=-155^{\circ} \mathrm{C}$ \\
\hline 5 & $\mathrm{P}=340 \mathrm{kPa}$ \\
\hline
\end{tabular}

Table 3. Simple cycle with mixed refrigerant conditions.

\begin{tabular}{|c|c|c|c|c|}
\hline Component & Base Case & Lee et al. (2002) & Del Nogal et al. (2005) & $\begin{array}{c}\text { Jensen \& Skogestad } \\
\mathbf{( 2 0 0 6 )}\end{array}$ \\
\hline Methane & 0.36 & 0.273 & 0.2712 & 0.2365 \\
\hline Ethane & 0.28 & 0.356 & 0.3721 & 0.3949 \\
\hline Propane & 0.11 & 0.052 & 0.0027 & 0.0000 \\
\hline Butane & 0.15 & 0.209 & 0.2531 & 0.2914 \\
\hline Nitrogen & 0.10 & 0.110 & 0.1008 & 0.0772 \\
\hline
\end{tabular}

Table 4. Compositions used for the mixed refrigerant in the simple cycle.

\section{Results and discussion}

In the following sections the results obtained for the simulations will be discussed, as well as the results for the sensitivity analysis carried out.

\subsection{Results for the cascade cycles}

In Fig. 9 and Fig. 10 are presented graphically the results for the flow rate, heat exchanged, $\mathrm{COP}$ and work required for each cycle in each configuration used. Configuration 1
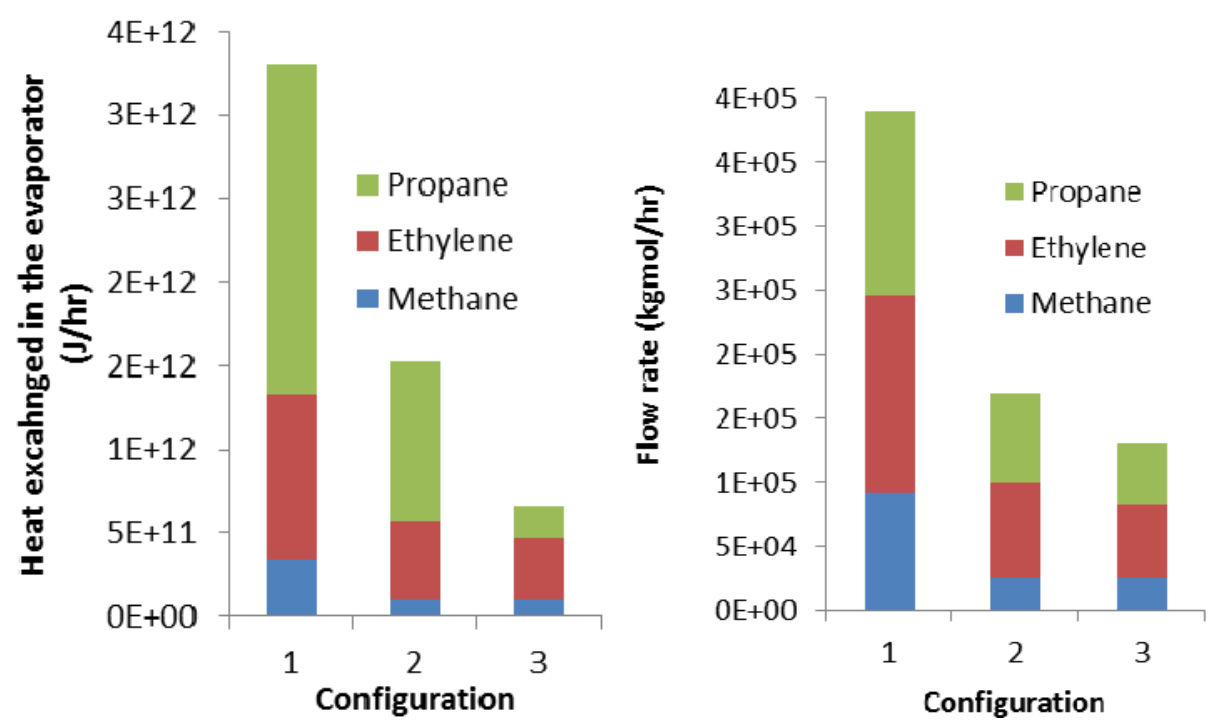

Fig. 9. Flow rate and heat exchanged results for the cascade cycles. 

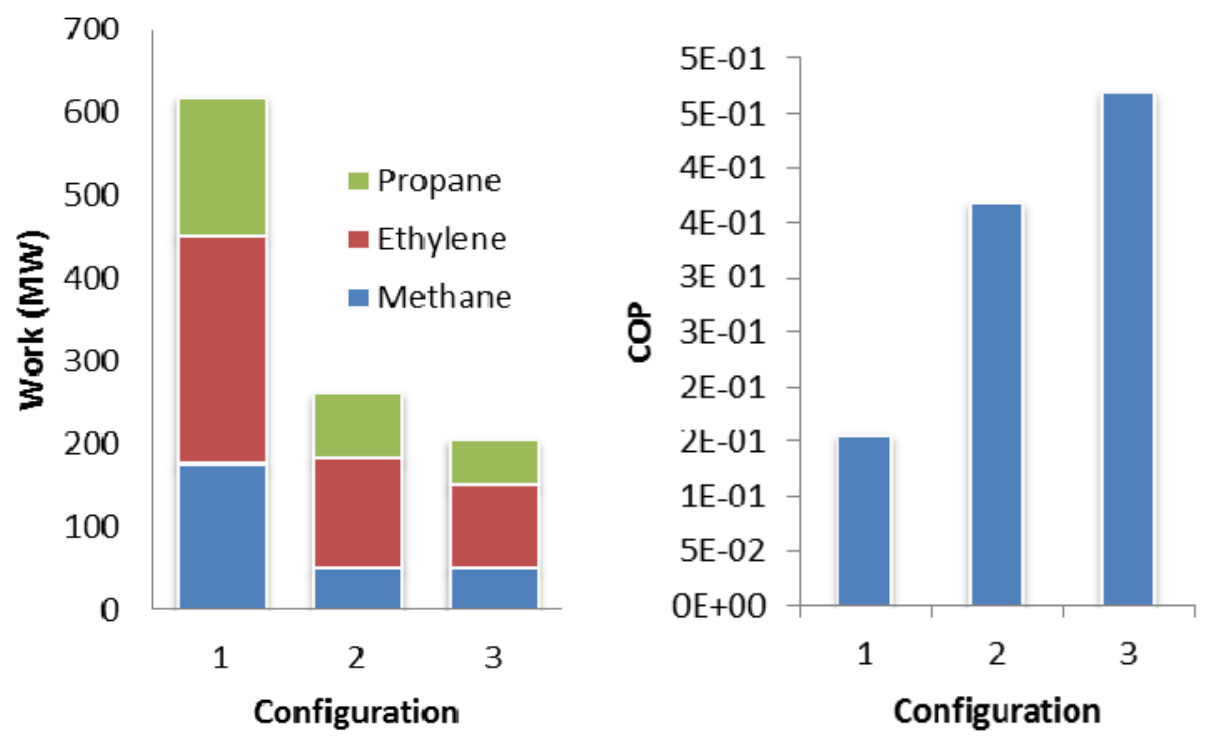

Fig. 10. Work required and COP of the cascades.

corresponds to the traditional cascade, configuration 2 to the hybrid cascade and configuration 3 to the triple cascade used for natural gas liquefaction.

It can be seen that, as commented previously, the use of the triple cascade is more convenient for the liquefaction of natural gas. It requires fewer amounts of refrigerants due to the less heat required to exchange in the evaporators. Moreover, the work required is less and as a consequence of these two effects, the COP of the cycle is improved greatly.

On the other hand, is important to note that other advantage of using the cascade cycles is the use of the propane for cooling the other refrigerats. Its heat capacity is greater, so it can exchange more energy using less flow rate.

In Table 5. Results for the traditional cascade are reported, along with the sensitivity analysis performed to the methane cycle. As one can expect, the compressor outlet pressure variation does not affects the valve outlet temperature because its outlet pressure corresponds to a saturation state, but it does affects the vaporized fraction after the valve. In the same way, the pressure variation at the valve outlet does not have consequences in the heat exchanged in the condenser.

The change in the flow rate of the lowest cycle modifies the energy balance in the common evaporator, so the flow rate of the other cycles changes in consequence. The work done in the compressor also varies due that it is presented as an extensive property.

Comparing the two parameters, the one with more impact in the operation was the outlet pressure of the lowest cycle. A variation of $12.5 \%$ in the pressure affects in more than $2 \%$ the COP value. 


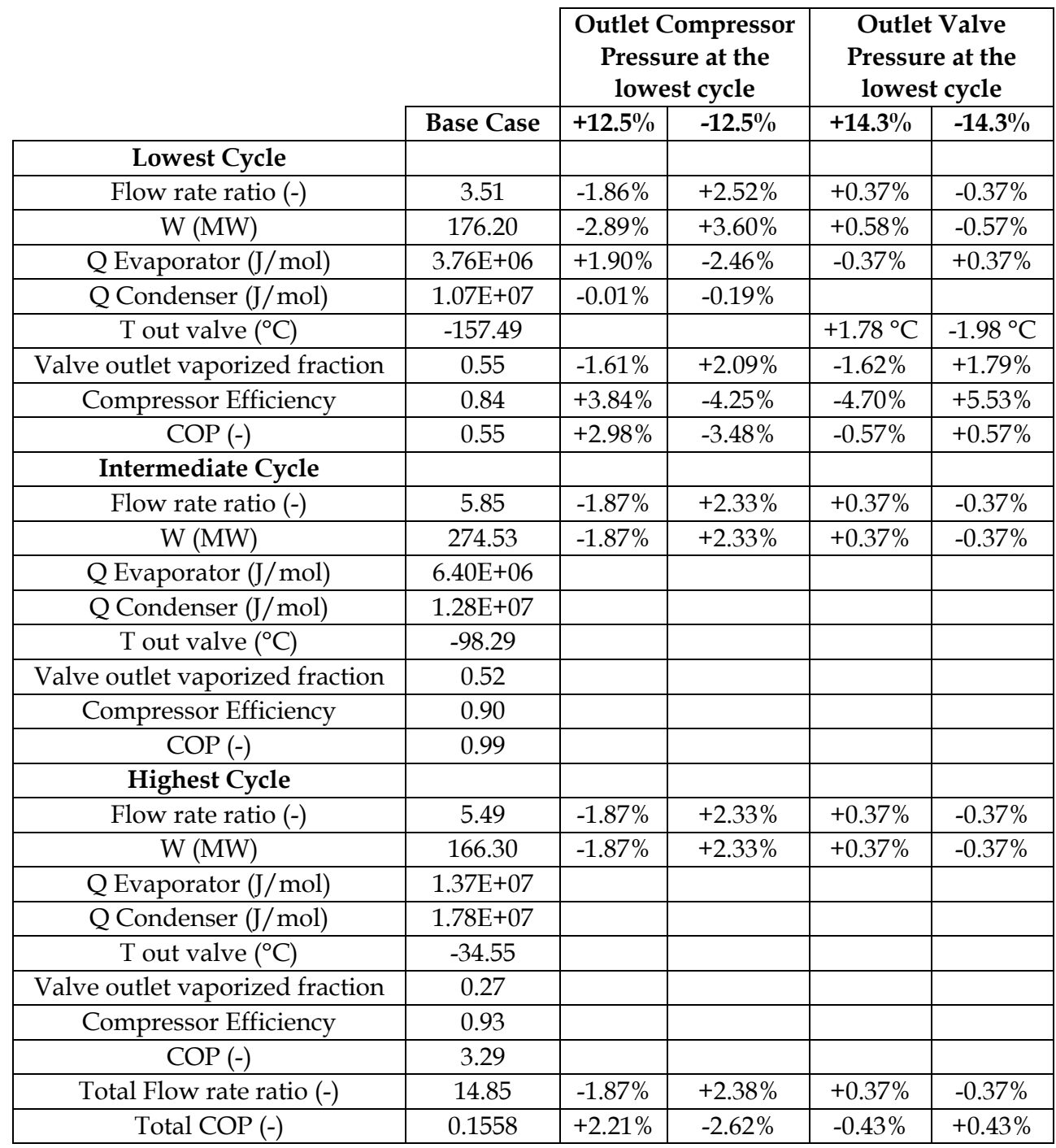

Table 5. Results for the traditional cascade.

The results for the hybrid cascade (as illustrated in Fig. 8) are presented in Table 6 and Table 7. Similar to the previous configurations, variation on the external cycles only affected the other cycles due to the change in the flow rates and thus in the evaporators energy balance.

The changes in the internal-lowest cycle only affected the internal-highest cycle. In particular it can be seen that variations in the compressor outlet pressure in the internallowest cycle has more impact than the variations due to the changes in the external cycle outlet compressor pressure. A modification of $20.5 \%$ in the highest pressure of the external cycle affects in around $4 \%$ the total COP. 


\begin{tabular}{|c|c|c|c|c|c|}
\hline \multirow[b]{3}{*}{ External Cycle } & \multirow[b]{3}{*}{ Base Case } & \multirow{2}{*}{\multicolumn{2}{|c|}{$\begin{array}{c}\text { Outlet Compressor } \\
\text { Pressure at the } \\
\text { external cycle }\end{array}$}} & \multirow{2}{*}{\multicolumn{2}{|c|}{$\begin{array}{l}\text { Outlet Valve } \\
\text { Pressure at the } \\
\text { external cycle }\end{array}$}} \\
\hline & & & & & \\
\hline & & $+12.5 \%$ & $-12.5 \%$ & $+14.3 \%$ & $-14.3 \%$ \\
\hline Flow rate ratio $(-)$ & 0.98 & $-1.91 \%$ & $+2.61 \%$ & $+0.37 \%$ & $-0.37 \%$ \\
\hline $\mathrm{W}(\mathrm{MW})$ & 49.43 & $-2.94 \%$ & $+3.69 \%$ & $+0.58 \%$ & $-0.57 \%$ \\
\hline Q Evaporator $1(\mathrm{~J} / \mathrm{mol})$ & $3.75 \mathrm{E}+06$ & $+1.95 \%$ & $-2.54 \%$ & $-0.37 \%$ & $+0.37 \%$ \\
\hline Q Evaporator $2(\mathrm{~J} / \mathrm{mol})$ & $-8.69 \mathrm{E}+06$ & $-0.31 \%$ & $+0.06 \%$ & & \\
\hline Q Condenser $(\mathrm{J} / \mathrm{mol})$ & $-1.96 \mathrm{E}+06$ & $+1.43 \%$ & $-1.40 \%$ & & \\
\hline T out valve $\left({ }^{\circ} \mathrm{C}\right)$ & -157.49 & & & $+1.78^{\circ} \mathrm{C}$ & $-1.98^{\circ} \mathrm{C}$ \\
\hline Valve oulet vaporized fraction & 0.55 & $-1.65 \%$ & $+2.15 \%$ & $-1.62 \%$ & $+1.79 \%$ \\
\hline Compressor Efficiency & 0.84 & $+3.84 \%$ & $-4.25 \%$ & $-4.70 \%$ & $+5.53 \%$ \\
\hline $\mathrm{COP}(-)$ & 0.54 & $+3.03 \%$ & $-3.56 \%$ & $-0.57 \%$ & $+0.57 \%$ \\
\hline \multicolumn{6}{|l|}{ Internal Lowest Cycle } \\
\hline Flow rate ratio $(-)$ & 2.80 & $-1.05 \%$ & $+1.26 \%$ & $+0.18 \%$ & $-0.17 \%$ \\
\hline $\mathrm{W}(\mathrm{MW})$ & 131.73 & $-1.05 \%$ & $+1.26 \%$ & $+0.18 \%$ & $-0.17 \%$ \\
\hline Q Evaporator $(\mathrm{J} / \mathrm{mol})$ & $6.44 \mathrm{E}+06$ & & & & \\
\hline Q Condenser $(\mathrm{J} / \mathrm{mol})$ & $-1.29 \mathrm{E}+07$ & & & & \\
\hline T out valve $\left({ }^{\circ} \mathrm{C}\right)$ & -98.29 & & & & \\
\hline Valve outlet vaporized fraction & 0.52 & & & & \\
\hline Compressor Efficiency & 0.90 & & & & \\
\hline $\operatorname{COP}(-)$ & 1.00 & & & & \\
\hline \multicolumn{6}{|l|}{ Internal Highest Cycle } \\
\hline Flow rate ratio $(-)$ & 2.64 & $-1.05 \%$ & $+1.26 \%$ & $+0.18 \%$ & $-0.17 \%$ \\
\hline $\mathrm{W}(\mathrm{MW})$ & 79.79 & $-1.05 \%$ & $+1.26 \%$ & $+0.18 \%$ & $-0.17 \%$ \\
\hline Q Evaporator $(\mathrm{J} / \mathrm{mol})$ & $1.37 \mathrm{E}+07$ & & & & \\
\hline Q Condenser $(\mathrm{J} / \mathrm{mol})$ & $-1.78 \mathrm{E}+07$ & & & & \\
\hline T out valve $\left({ }^{\circ} \mathrm{C}\right)$ & -34.55 & & & & \\
\hline Valve outlet vaporized fraction & 0.27 & & & & \\
\hline Compressor Efficiency & 0.93 & & & & \\
\hline COP (-) & 3.30 & & & & \\
\hline Total Work (MW) & 260.95 & $-1.41 \%$ & $+1.72 \%$ & $+0.25 \%$ & $-0.25 \%$ \\
\hline COP total (-) & 0.3684 & $+1.43 \%$ & $-1.69 \%$ & $-0.25 \%$ & $+0.25 \%$ \\
\hline
\end{tabular}

Table 6. Results for the hybrid cascade. 


\begin{tabular}{|c|c|c|c|c|}
\cline { 2 - 5 } \multicolumn{1}{c|}{} & \multicolumn{2}{|c|}{$\begin{array}{c}\text { Outlet Compressor Pressure } \\
\text { at the internal-lowest cycle }\end{array}$} & $\begin{array}{c}\text { Outlet Valve Pressure at the } \\
\text { internal-lowest cycle }\end{array}$ \\
\hline Internal-Lowes Cycle & $\mathbf{+ 2 0 . 5 \%}$ & $\mathbf{- 2 0 . 5 \%}$ & $\mathbf{+ 1 4 . 3 \%}$ & $\mathbf{- 1 4 . 3 \%}$ \\
\hline Flow rate ratio (-) & $+8.90 \%$ & $-8.26 \%$ & $+0.31 \%$ & $-0.31 \%$ \\
\hline $\mathrm{W}(\mathrm{MW})$ & $+6.27 \%$ & $-6.09 \%$ & $+0.62 \%$ & $-0.61 \%$ \\
\hline Q Evaporator (J/mol) & $-8.17 \%$ & $+9.01 \%$ & $-0.31 \%$ & $+0.31 \%$ \\
\hline Q Condenser (J/mol) & $-5.29 \%$ & $+5.69 \%$ & & \\
\hline T out valve ( $\left.{ }^{\circ} \mathrm{C}\right)$ & & & $-0.03{ }^{\circ} \mathrm{C}$ & $+0.03{ }^{\circ} \mathrm{C}$ \\
\hline Valve outlet vaporized fraction & $+7.69 \%$ & $-8.48 \%$ & $-1.65 \%$ & $+1.82 \%$ \\
\hline Compressor Efficiency & $+7.90 \%$ & $-9.20 \%$ & $-5.92 \%$ & $+6.98 \%$ \\
\hline COP (-) & $-5.90 \%$ & $+6.48 \%$ & $-0.62 \%$ & $+0.62 \%$ \\
\hline Internal Highest Cycle & & & & \\
\hline Flow rate ratio (-) & $+3.14 \%$ & $-3.05 \%$ & $+0.31 \%$ & $-0.31 \%$ \\
\hline W (MW) & $+3.14 \%$ & $-3.05 \%$ & $+0.31 \%$ & $-0.31 \%$ \\
\hline COP (-) & & & & \\
\hline Total Work (MW) & $+4.13 \%$ & $-4.00 \%$ & $+0.41 \%$ & $-0.40 \%$ \\
\hline COP total (-) & $-3.96 \%$ & $+4.17 \%$ & $-0.41 \%$ & $+0.41 \%$ \\
\hline
\end{tabular}

Table 7. Results for the hybrid cascade (continued).

The results for the triple cascade (as illustrated in Fig. 5) are shown in Table 8, Table 9, and Table 10. As in the previous cases, the hierarchy of the changes is from the external to the internal cycles, and the variations in the internal cycles did not affect the externals.

The sensitivity of the variations in the external cycle high pressure is slightly higher than in the intermediate cycle. A $12.5 \%$ variation of the outlet compressor pressure in the external cycle changes more than $1.75 \%$ the total COP of the system.

In Table 11 is reported the most relevant results for the sensitivity analysis. It is shown the results on the COP and on the total flow rate. The first gives an idea about the cycle performance, and the later about the equipment size required.

\subsection{Results for the simple cycle using mixed refrigerant}

In Table 12 are reported the sensitivity study for the simple cycle using mixed refrigerant. It can be seen that the high pressure of the cycle affects more the COP than the low pressure. In particular, a decrease of $10 \%$ in the high pressure produces a diminution of the COP by $8.48 \%$.

On the other hand, on Table 13 are presented the results with other optimized compositions found in the literature. It is important to note that even if these compositions where optimized using particular conditions, using them results in an increase in the COP. 


\begin{tabular}{|c|c|c|c|c|c|c|}
\hline & \multirow[b]{2}{*}{ Base Case } & \multicolumn{2}{|c|}{$\begin{array}{l}\text { Outlet Compressor } \\
\text { Pressure at the } \\
\text { external cycle }\end{array}$} & \multicolumn{2}{|c|}{$\begin{array}{l}\text { Outlet Valve } \\
\text { Pressure at the } \\
\text { external cycle }\end{array}$} \\
\hline & & & $+12.5 \%$ & $-12.5 \%$ & $+14.3 \%$ & $-14.3 \%$ \\
\hline \multirow{10}{*}{ 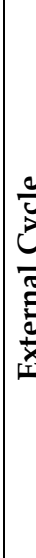 } & Flow rate ratio $(-)$ & 0.99 & $-1.96 \%$ & $+2.69 \%$ & $+0.37 \%$ & $-0.37 \%$ \\
\hline & $\mathrm{W}(\mathrm{MW})$ & 49.58 & $-2.99 \%$ & $+3.78 \%$ & $+0.58 \%$ & $-0.57 \%$ \\
\hline & Q Evaporator $1(\mathrm{~J} / \mathrm{mol})$ & $3.75 \mathrm{E}+06$ & $+2.00 \%$ & $-2.62 \%$ & $-0.37 \%$ & $+0.37 \%$ \\
\hline & Q Evaporator $2(\mathrm{~J} / \mathrm{mol})$ & $-6.97 \mathrm{E}+06$ & $-1.04 \%$ & $+0.66 \%$ & & \\
\hline & Q Evaporator $3(\mathrm{~J} / \mathrm{mol})$ & $-1.72 \mathrm{E}+06$ & $+2.72 \%$ & $-2.55 \%$ & & \\
\hline & Q Condenser $(\mathrm{J} / \mathrm{mol})$ & $-1.96 \mathrm{E}+06$ & $+1.43 \%$ & $-1.40 \%$ & & \\
\hline & T out valve $\left({ }^{\circ} \mathrm{C}\right)$ & -157.49 & & & $+1.78^{\circ} \mathrm{C}$ & $-1.98^{\circ} \mathrm{C}$ \\
\hline & Valve outlet vaporized fraction & 0.55 & $-1.69 \%$ & $+2.21 \%$ & $-1.61 \%$ & $+1.78 \%$ \\
\hline & Compressor Efficiency & 0.84 & $+3.84 \%$ & $-4.25 \%$ & $-4.70 \%$ & $+5.53 \%$ \\
\hline & $\mathrm{COP}(-)$ & 0.54 & $+3.08 \%$ & $-3.64 \%$ & $-0.57 \%$ & $+0.57 \%$ \\
\hline \multirow{9}{*}{ 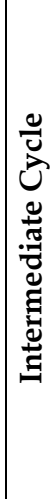 } & Flow rate ratio (-) & 2.16 & $-1.45 \%$ & $+1.64 \%$ & $+0.18 \%$ & $-0.18 \%$ \\
\hline & $\mathrm{W}(\mathrm{MW})$ & 101.13 & $-1.45 \%$ & $+1.64 \%$ & $+0.18 \%$ & $-0.18 \%$ \\
\hline & Q Evaporator $2(\mathrm{~J} / \mathrm{mol})$ & $6.53 \mathrm{E}+06$ & & & & \\
\hline & Q Evaporator $3(\mathrm{~J} / \mathrm{mol})$ & $-9.52 \mathrm{E}+06$ & & & & \\
\hline & Q Condenser $(\mathrm{J} / \mathrm{mol})$ & $-3.34 \mathrm{E}+06$ & & & & \\
\hline & T out valve $\left({ }^{\circ} \mathrm{C}\right)$ & -98.29 & & & & \\
\hline & Valve outlet vaporized fraction & 0.52 & & & & \\
\hline & Compressor Efficiency & 0.91 & & & & \\
\hline & $\mathrm{COP}(-)$ & 1.02 & & & & \\
\hline \multirow{9}{*}{ 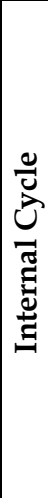 } & Flow rate ratio (-) & 1.80 & $-1.17 \%$ & $+1.38 \%$ & $+0.18 \%$ & $-0.18 \%$ \\
\hline & $\mathrm{W}(\mathrm{MW})$ & 54.37 & $-1.17 \%$ & $+1.38 \%$ & $+0.18 \%$ & $-0.18 \%$ \\
\hline & Q Evaporator $(\mathrm{J} / \mathrm{mol})$ & $1.37 \mathrm{E}+07$ & & & & \\
\hline & Q Condenser $(\mathrm{J} / \mathrm{mol})$ & $-1.78 \mathrm{E}+07$ & & & & \\
\hline & T out valve $\left({ }^{\circ} \mathrm{C}\right)$ & -34.55 & & & & \\
\hline & Valve outlet vaporized fraction & 0.27 & & & & \\
\hline & Compressor Efficiency & 0.93 & & & & \\
\hline & $\mathrm{COP}(-)$ & 3.29 & & & & \\
\hline & Total COP (-) & 0.4695 & $+1.78 \%$ & $-2.05 \%$ & $-0.28 \%$ & $+0.27 \%$ \\
\hline
\end{tabular}

Table 8. Results for the triple cascade. 


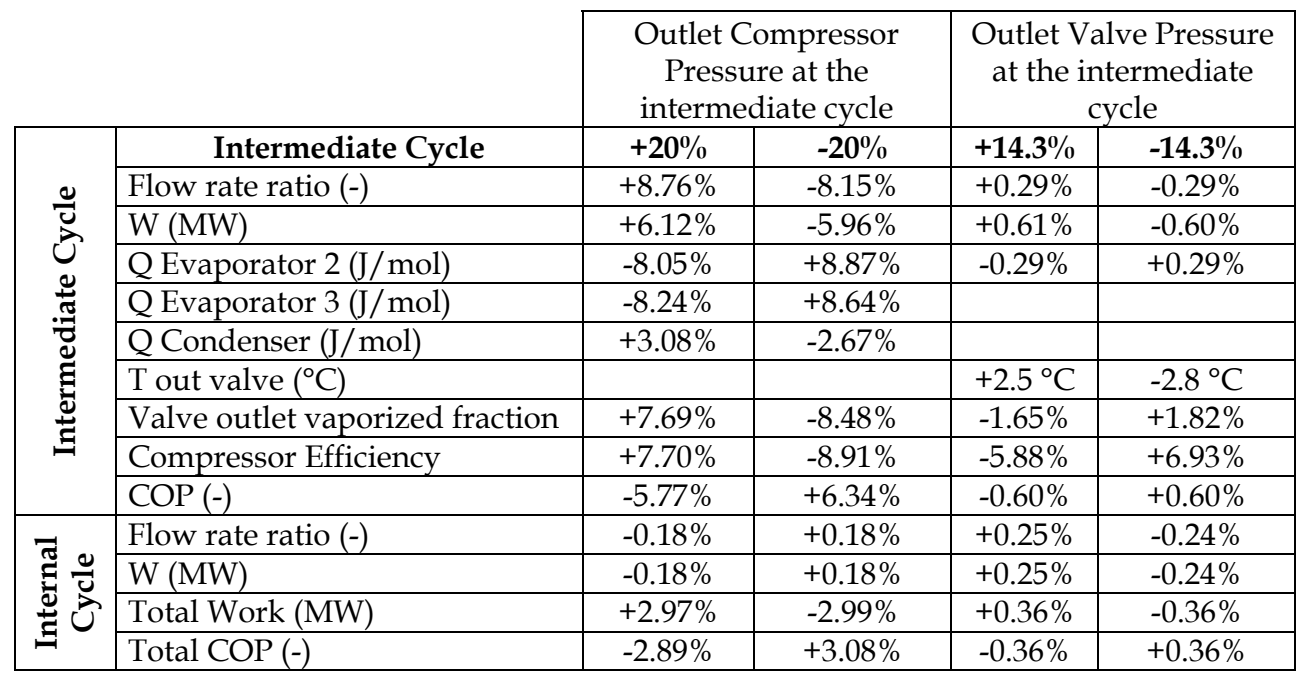

Table 9. Results for the triple cascade (continued).

\begin{tabular}{|c|c|c|c|c|}
\cline { 2 - 5 } \multicolumn{1}{c|}{} & \multicolumn{2}{c|}{$\begin{array}{c}\text { Outlet Compressor Pressure } \\
\text { at the internal cycle }\end{array}$} & $\begin{array}{c}\text { Outlet Valve Pressure at } \\
\text { the internal cycle }\end{array}$ \\
\hline Internal Cycle & $\mathbf{+ 7 . 1 4} \%$ & $\mathbf{- 7 . 1 4 \%}$ & $\mathbf{+ 1 4 . 3 \%}$ & $\mathbf{- 1 4 . 3 \%}$ \\
\hline Flow rate ratio (-) & $-0.001 \%$ & $+0.001 \%$ & $+0.23 \%$ & $-0.23 \%$ \\
\hline W (MW) & $-1.56 \%$ & $+1.53 \%$ & $+1.00 \%$ & $-0.98 \%$ \\
\hline Q Evaporator $(\mathrm{J} / \mathrm{mol})$ & $+0.001 \%$ & $-0.001 \%$ & $-0.23 \%$ & $+0.23 \%$ \\
\hline Q Condenser $(\mathrm{J} / \mathrm{mol})$ & $-0.36 \%$ & $+0.36 \%$ & & \\
\hline T out valve $\left({ }^{\circ} \mathrm{C}\right)$ & & & $+3.32{ }^{\circ} \mathrm{C}$ & $-3.72{ }^{\circ} \mathrm{C}$ \\
\hline Valve outlet vaporized fraction & $-0.003 \%$ & $+0.003 \%$ & $-5.88 \%$ & $+6.41 \%$ \\
\hline Compressor Efficiency & $+4.52 \%$ & $-4.65 \%$ & $-9.29 \%$ & $+11.01 \%$ \\
\hline COP $(-)$ & $+1.58 \%$ & $-1.51 \%$ & $-0.99 \%$ & $+0.99 \%$ \\
\hline Total Flow rate ratio $(-)$ & $-0.0003 \%$ & $+0.0004 \%$ & $+0.08 \%$ & $-0.08 \%$ \\
\hline Total Work (MW) & $-0.41 \%$ & $+0.41 \%$ & $+0.27 \%$ & $-0.26 \%$ \\
\hline Total COP $(-)$ & $+0.41 \%$ & $-0.40 \%$ & $-0.26 \%$ & $+0.26 \%$ \\
\hline
\end{tabular}

Table 10. Results for the triple cascade (continued).

\begin{tabular}{|c|c|c|c|c|}
\hline Configuration & Variable & Variation & $\begin{array}{c}\text { Sensitivity } \\
\text { on the COP }\end{array}$ & $\begin{array}{c}\text { Sensitivity on } \\
\text { the Flow Rate }\end{array}$ \\
\hline $\begin{array}{c}\text { Traditional } \\
\text { Cascade }\end{array}$ & $\begin{array}{c}\text { Lowest cycle high } \\
\text { pressure }\end{array}$ & $-12.5 \%$ & $-2.62 \%$ & $+2.38 \%$ \\
\hline Hybrid Cascade & $\begin{array}{c}\text { Internal-lowest cycle } \\
\text { high pressure }\end{array}$ & $-20.5 \%$ & $+4.17 \%$ & $-4.86 \%$ \\
\hline Triple Cascade & $\begin{array}{c}\text { External cycle high } \\
\text { pressure }\end{array}$ & $-12.5 \%$ & $-2.05 \%$ & $+1.76 \%$ \\
\hline
\end{tabular}

Table 11. Summary of the sensitivity analisys for the cascades. 


\begin{tabular}{|c|c|c|c|c|c|}
\cline { 3 - 5 } \multicolumn{2}{c|}{} & \multicolumn{2}{c|}{ High Pressure } & \multicolumn{2}{c|}{ Low Pressure } \\
\cline { 2 - 6 } \multicolumn{1}{c|}{} & Base Case & $+10 \%$ & $-10 \%$ & $+16.67 \%$ & $-16.67 \%$ \\
\hline Flow rate ratio $(-)$ & 2.69 & $-6.71 \%$ & $+8.24 \%$ & $+0.60 \%$ & $-0.59 \%$ \\
\hline $\mathrm{W}(\mathrm{J} / \mathrm{mol})$ & $7.26 \mathrm{E}+06$ & $-1.29 \%$ & $+1.27 \%$ & $+0.40 \%$ & $-0.40 \%$ \\
\hline $\mathrm{W}(\mathrm{MW})$ & 142.41 & $-8.09 \%$ & $+9.62 \%$ & $+1.00 \%$ & $-0.98 \%$ \\
\hline Q Evaporator $1(\mathrm{~J} / \mathrm{mol})$ & $-1.67 \mathrm{E}+07$ & $-2.08 \%$ & $+2.30 \%$ & & \\
\hline Q Evaporator 2 $(\mathrm{J} / \mathrm{mol})$ & $2.16 \mathrm{E}+07$ & $-0.05 \%$ & $+0.05 \%$ & $-0.13 \%$ & $+0.13 \%$ \\
\hline Q Condenser $(\mathrm{J} / \mathrm{mol})$ & $-1.22 \mathrm{E}+07$ & $+1.91 \%$ & $-2.31 \%$ & & \\
\hline T out valve $\left({ }^{\circ} \mathrm{C}\right)$ & -157.05 & $+0.11{ }^{\circ} \mathrm{C}$ & $-0,11{ }^{\circ} \mathrm{C}$ & $+0,93{ }^{\circ} \mathrm{C}$ & $-1.04{ }^{\circ} \mathrm{C}$ \\
\hline Valve outlet vaporized fraction & 0.04 & $+1.61 \%$ & $-1.64 \%$ & $-25.99 \%$ & $+27.82 \%$ \\
\hline Compressor Efficiency & 0.85 & $+4.81 \%$ & $-5.41 \%$ & $-6.97 \%$ & $+8.14 \%$ \\
\hline COP $(-)$ & 0.67 & $+7.49 \%$ & $-8.78 \%$ & $-0.99 \%$ & $+0.99 \%$ \\
\hline
\end{tabular}

Table 12. Results for the simple cycle with mixed refrigerant.

\begin{tabular}{|c|c|c|c|}
\cline { 2 - 4 } \multicolumn{1}{c|}{} & $\begin{array}{c}\text { Lee et al. } \\
(2002)\end{array}$ & $\begin{array}{c}\text { Del Nogal et al. } \\
(2005)\end{array}$ & $\begin{array}{c}\text { Jensen \& Skogestad } \\
(2006)\end{array}$ \\
\hline Flow rate ratio $(-)$ & $-25.56 \%$ & $-32.19 \%$ & $-20.31 \%$ \\
\hline W $(\mathrm{J} / \mathrm{mol})$ & $+3.15 \%$ & $+19.62 \%$ & $-11.67 \%$ \\
\hline $\mathrm{W}(\mathrm{MW})$ & $-23.22 \%$ & $-18.88 \%$ & $-29.61 \%$ \\
\hline Q Evaporator $1(\mathrm{~J} / \mathrm{mol})$ & $-6.75 \%$ & $-8.53 \%$ & $+8.35 \%$ \\
\hline Q Evaporator $2(\mathrm{~J} / \mathrm{mol})$ & $+2.56 \%$ & $+4.16 \%$ & $+12.23 \%$ \\
\hline Q Condenser $(\mathrm{J} / \mathrm{mol})$ & $+15.72 \%$ & $+30.84 \%$ & $+3.30 \%$ \\
\hline T out valve $\left({ }^{\circ} \mathrm{C}\right)$ & $+0.46{ }^{\circ} \mathrm{C}$ & $-0.01{ }^{\circ} \mathrm{C}$ & $-0.03{ }^{\circ} \mathrm{C}$ \\
\hline Valve outlet vaporized fraction & $+11.83 \%$ & $+33.19 \%$ & $-6.96 \%$ \\
\hline Compressor Efficiency & $-0.01 \%$ & $+0.03 \%$ & $+0.05 \%$ \\
\hline COP $(-)$ & $+30.24 \%$ & $+23.28 \%$ & $+42.06 \%$ \\
\hline
\end{tabular}

Table 13. Results for the simple cycle with mixed refrigerant (continued).

In order to use them it was necessary to adjust the high pressure to guarantee a valve outlet temperature of $-157^{\circ} \mathrm{C}$. In all the cases the minimum temperature approach (MITA) of the temperature profiles inside the evaporator was checked in order to avoid temperature cross.

When using the compositions of Table 4, also the suction temperature of the compressor was changed, in order to have a MITA of at least $2{ }^{\circ} \mathrm{C}$. The discharge temperature of the compressor was adjusted so the polytropic efficiency was $85 \%$.

It must be noted that the amount the heat exchanged on each refrigerant pass in the evaporator must be maximized, in this way the difference in heat exchanged in each pass of is the heat retired from the natural gas, so the greater this quantity is, the less refrigerant would be used and the greater the COP.

This can be seen in Table 13, the mixture whit a greater heat transferred in each pass of the evaporator is the one proposed by Jensen \& Skogestad (2006), which has the greater COP.

When comparing the results of the triple cascade with pure refrigerant and the simple cycle with mixed refrigerant can be seen that the later has the greatest COP and also the smallest 
and the smaller power consumption and refrigerant flow rate. Nevertheless, the advantage of the cascade cycle is its simpler operation, so the any decision on the technology selection should be studied carefully.

\section{Conclusions}

Starting with two of the most used technologies for natural gas liquefaction, it was possible to model and simulate the system using Matlab ${ }^{\circledR}$ routines and using the thermodynamic model of Peng-Robinson for calculating energetic properties of the fluids, which leaded to the calculation of heats and powers of the cycle.

It was also possibly to perform a sensitivity analysis of some of the variables of the cycle and it was obtained that the most affecting variables are the high pressure of the external cycle (for the cascades) and the high pressure of the simple cycle with mixed refrigerant.

Other compositions found in the literature were tested for the simple cycle. It was observed that every different composition could affect the performance, and we recommend performing an optimization using these operating conditions, in order to maximize the COP.

\section{References}

Aspelund, A.; Gundersen, T.; Myklebust, J.; Nowak, M. P. \& Tomasgard, A. (2010). An Optimization-Simulation Model for a Simple LNG Process. Computers $\mathcal{E}$ Chemical Engineering, Vol. 34, No.10, (October 2010), pp. 1606-1617, ISSN: 0098-1354.

British Petroleum. (2011). Natural Gas. In: BP Statistical Review of World Energy, June 2011, Available from http://www.bp.com/statisticalreview

Çengel, Y. \& Boles, M. (2006). Thermodynamics: An Engineering Approach, McGraw-Hill, 9780070606593.

Del Nogal, F. L.; Kim, J.; Smith, R. \& Perry, S. J. (2005). Improved Design of Mixed Refrigerant Cycles Using Mathematical Programming. GPA Europe Meeting: GTL and LNG in Europe, Amsterdam, Febrary, 2005.

Green, D. W. \& Perry, R. H. (2008). Perry's Chemical Engineering Handbook (8th. ed.), McGraw-Hill, 0-07-154209-4.

Haselden, G. G. (1977). The Liquefaction of Natural Gas. Contemporary Physics, Vol. 18, No.5, 471-488, ISSN: 1366-5812.

Institute for Energy, Law \& Enterprise. University of Houston. (2003). An Overview on Liquefied Natural Gas (LNG), Its Properties, the LNG Industry, Safety Considerations. Available from http://www.energy.uh.edu

Jensen, J. B. \& Skogestad, S. (2006). Optimal Operation of a Simple LNG Process. International Symposium on advanced control of chemical processes (ADCHEM), Gramado - Brazil, April 2-5, 2006.

Lee, G. C.; Smith, R. \& Zhu, X. X. (2002). Optimal Synthesis of Mixed-Refrigerant Systems for Low-Temperature Processes. Industrial Chemical Engineering Research, Vol. 41, No.20, (August 2002), pp. 5016-5028, ISSN: 1520-5045.

Lemmon, E.W.; McLinden, M.O. \& Friend, D.G. . (2005). Thermophysical Properties of Fluid Systems. In: NIST Chemistry WebBook, NIST Standard Reference Database Number 69, October 2011, Available from http:/ / webbook.nist.gov 
Nikos, V. (1986). Phase Behavior of Systems Compressing Noth Sea Reservoir Fluids and Injection Gases. Journal of Petroleum Technology, Vol. XXII, 1221-1233.

Peng, D.-Y. \& Robinson, D. B. (1976). A New Two Constant Equation of State. Industrial E Engineering Chemistry Fundamentals, Vol. 15, No.1, (Febraury 1976), pp. 59-64.

Price, B. C. \& Mortko, R. A. (1996). Prico - a Simple, Flexible Proven Approach to Natural Gas Liquefaction. GASTECH, LNG, Natural Gas, LPG international conference, Vienna, 1996.

Smith, R. (2005). Chemical Process: Design and Integration (1st. ed.), Wiley, 978-0471486817.

Walas, S. M. (1990). Chemical Process Equipment Selection and Design, ButterworthHeinemann, 0-7506-9385-1. 


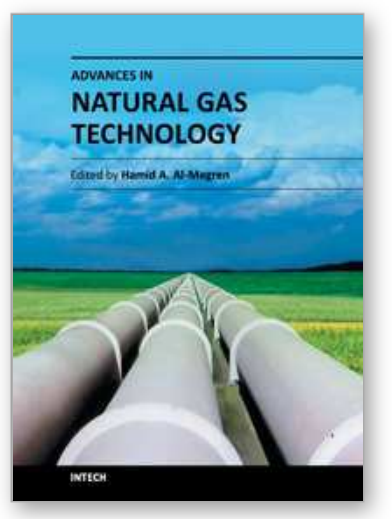

\author{
Advances in Natural Gas Technology \\ Edited by Dr. Hamid Al-Megren
}

ISBN 978-953-51-0507-7

Hard cover, 542 pages

Publisher InTech

Published online 11, April, 2012

Published in print edition April, 2012

Natural gas is a vital component of the world's supply of energy and an important source of many bulk chemicals and speciality chemicals. It is one of the cleanest, safest, and most useful of all energy sources, and helps to meet the world's rising demand for cleaner energy into the future. However, exploring, producing and bringing gas to the user or converting gas into desired chemicals is a systematical engineering project, and every step requires thorough understanding of gas and the surrounding environment. Any advances in the process link could make a step change in gas industry. There have been increasing efforts in gas industry in recent years. With state-of-the-art contributions by leading experts in the field, this book addressed the technology advances in natural gas industry.

\title{
How to reference
}

In order to correctly reference this scholarly work, feel free to copy and paste the following:

Alessandro Trigilio, Alexis Bouza and Sabrina Di Scipio (2012). Modelling and Simulation of Natural Gas Liquefaction Process, Advances in Natural Gas Technology, Dr. Hamid Al-Megren (Ed.), ISBN: 978-953-510507-7, InTech, Available from: http://www.intechopen.com/books/advances-in-natural-gas-technology/modelling-and-simulation-of-natural-gas-liquefaction-process

\section{INTECH}

open science | open minds

\section{InTech Europe}

University Campus STeP Ri

Slavka Krautzeka 83/A

51000 Rijeka, Croatia

Phone: +385 (51) 770447

Fax: +385 (51) 686166

www.intechopen.com

\section{InTech China}

Unit 405, Office Block, Hotel Equatorial Shanghai

No.65, Yan An Road (West), Shanghai, 200040, China

中国上海市延安西路65号上海国际贵都大饭店办公楼405单元

Phone: +86-21-62489820

Fax: $+86-21-62489821$ 
(C) 2012 The Author(s). Licensee IntechOpen. This is an open access article distributed under the terms of the Creative Commons Attribution 3.0 License, which permits unrestricted use, distribution, and reproduction in any medium, provided the original work is properly cited. 